\title{
建築外装構成要素の幾何学特性がパターン知覚の印象評価に与える影響 一外装材のランバス状パターンに関する検討一

\author{
EFFECT OF GEOMETRIC PROPERTIES OF BUILDING FACADE ELEMENTS \\ ON IMPRESSIVE EVALUATION \\ - Rhombic pattern of building facade-
}

細谷基之*, 橘高義典**, 田村 雅 紀*** Motoyuki HOSOYA, Yoshinori KITSUTAKA and Masaki TAMURA

\begin{abstract}
In this paper, the effect of geometric properties of building facade elements on the visual evaluation was investigated. By the data of observation on the actual state of recent building facades which were designed by worldwide famous architects, the rhombic pattern was selected in this study as an important elements affecting the building impression. The factors influencing the visual evaluation of rhombic patterns such as dimension and rhombic pattern edge angle of element were analyzed by performing the sensory test using the simulated specimen. As the results of the sensory tests, the rhombic patterns which has medium edge angle and medium dimension of element tends to obtain relatively good evaluation.
\end{abstract}

Keywords : external materials, texture, sensory test, impressive evaluation, rhombic pattern 外装材、テクスチャ、官能検查、印象評価、ランバス状パターン

\section{1. 研究の背景と目的}

現在、建築外装のデザインは、コンピュータによる構造解析なら びに施工技術の向上などにより、従来のように構造形式や内部空間 による制約を受けずに、比較的自由に構成できるようになったわ。つ まり建築外観の見せ方の価値が高まり、外装が「表層」という 1 つ のデザイン領域として確立される傾向にあるためと考えられる。さ らには、外装の構成要素に構造を負担する性質を与えた上で、その 外装により構造形式や内部空間が決定されるような事例も見られる。 一方で、既存の学校建築を対象に、躯体柱間に鉄骨ブレースを挿入 して耐震補強をする事例2 が増えており、外装の印象に影響を与える 可能性も考えられる。このような状況においては、建築外装の印象 が重要視される可能性があり、外装の構成要素を設計する際に、形 状、モジュールの寸法を決定するための新たな手がかり・評価デー タなどが必要となってくる。

建築外装におけるテクスチャを扱った研究は 2 つ分けられる。1 つは素材の表面性状としてテクスチャを捉えたもの角(4)5)67)、もう1つ は外装を構成する要素の形状とその配列による幾何学的印象として

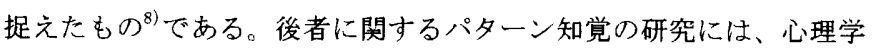
分野のものが多数あるが、建築外装を幾何学パターンとしてとらえ た研究事例は少ない。

本研究では、建築外装の構成要素の幾何学的な性質が印象評価に
与える影響を検討する。その目的は、建筑外装の構成要素であるパ ネルの形・大きさに注目したパターンとしての外装の見え方を官能 検査により定量的に把握するとともに、繰り返される要素によって 構成された建築外装が、どのように知覚され、印象を与えるかを予 測するための基礎的な知見を得ることにある。

研究方法は、外装パターンについて分析を行い、それを類型化す る。続いて研究対象としてランバスパターンを設定し、官能検查の ための事前調査として実際の建築事例の調査を通してランバス状パ ターンの構成手法を調べる。そして、官能検査により印象評価を行 い、建築外装構成要素の幾何学特性がパターン知覚の印象評価に与 える影響を検証する。

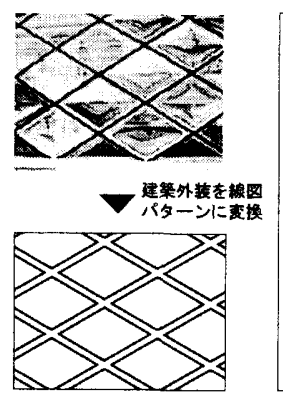

図1 モデル化プロセス

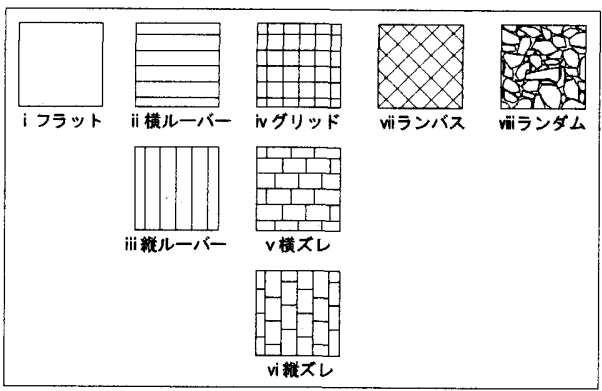

図2 パターン分類図
* 首都大学東京大学院工学研究科建築学専攻 修士課程

** 首都大学東京大学院工学研究科建築学専攻 教授・工博

*** 首都大学東京大学院工学研究科建築学尃攻 助手. 博士 (工学)
Graduate Student, Dept. of Archi., Graduate School of Eng. Tokyo Metro. Univ. Prof., Dept. of Archi. Graduate School of Eng. Tokyo Metro. Univ., Dr. Eng. Research Assoc., Dept. of Archi. Graduate School of Eng. Tokyo Metro. Univ., Dr. Eng. 


\section{2. 外装パターンの幾何学特性の分析}

\section{1 外装パターンの分類}

実際の建築外装は様々な材料で構成され、それらは様々な形状の パネル・部材に加工され建築の外壁として割付けられている。本研 究では、この外装パターンの構成要素の幾何学特性を調べるため、 図1のように、外装パターンを線図パターンへ変換した上で、このパ ターンを図2のように大きく8グループ（フラット、繸ルーバー、横 ルーバー、直交グリッド、繸ズレ、横ズレ、ランバス、ランダム) に分類をした。なお、図2の分類は「表層」を扱う代表的な建築家の

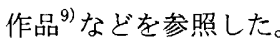

\section{2 各種外装パターンの特徴}

建築外装を単純なパターンに置き換えると、建築の構造や内部構 成の規則性が表れているものと、建築を包むものとして内部に対し て自由に構成されたものに分けられ(10)、それらは、繸ルーバー、横 ルーバー、直交グリッド、繸ズレ、横ズレのグループとランバス、 ランダムのグループで構成されると考えられる。前者は建築の柱、 梁、壁、スラブなどの垂直水平材を構成要素とするパターンであり 建築のイメージを想起させる一般的な外装パターンといえる。後者 は、垂直水平の要素がなく、建築内部の構成とは乘離している自由 な形、大きさの要素によって構成された表層としての外装パターン として位置づけられる。

\section{3 ランバス状パターンの事例抽出}

以上の考察から、本研究では、表層として特徵的な外装として認 められるランバス状パターン10)を取り上げる。

ランバス状パターンの幾何学特性と印象の関倸を調べるために、 ランバス状外装を採用している建筑事例を抽出・分析し、表層とし てのランバス状外装構成の決定要因や幾何学特性を明らかにする。

以下の(1)、(2)、(3)、(4)に、事例抽出のための条件を示す。

(1)斜交材を使用したランバス状外装により構成されている。

(2)外装が建築の構造や内部構成から影響を受けずに、デザインさ れた表層であること。

(3)西暦1999 -2005年に計画もしくは竣工した現代建築。

(4)外装の使用材料は限定しない。

\section{4 ランバス状外装の事例分析}

表1に、上記(1)一(4)のランバス状外装抽出条件より抽出した10件の 事例を示す。これらの事例における外装構成手法の分析結果より、 ランバスグリッドの構成要素である等辺四角形の「大きさ」、「形 状」を決定する要因には様々な手法があることが確認された。

事例 $(d, f, j)$ では、ランバス状外装が複雑で不定形な形態を覆って おり、コンピュータによる構造解析の結果、応力が集中する部分を 補うようにパターンの密度を変化させる、材の径を太くするなどの

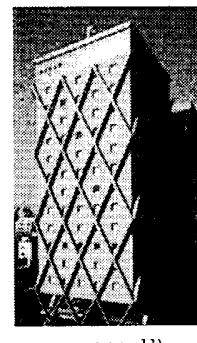

事(例a $\left.{ }^{11}\right)$

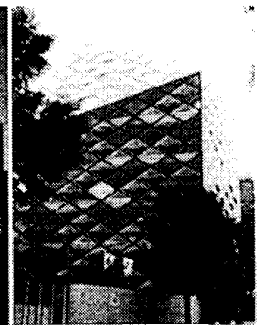

事例d

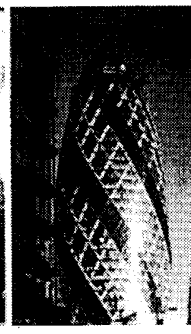

事例e ${ }^{12)}$

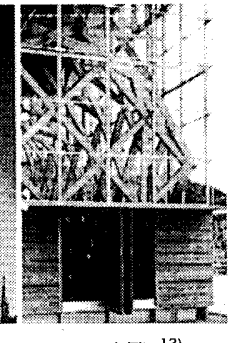

事例h 13)
表1 事例分析

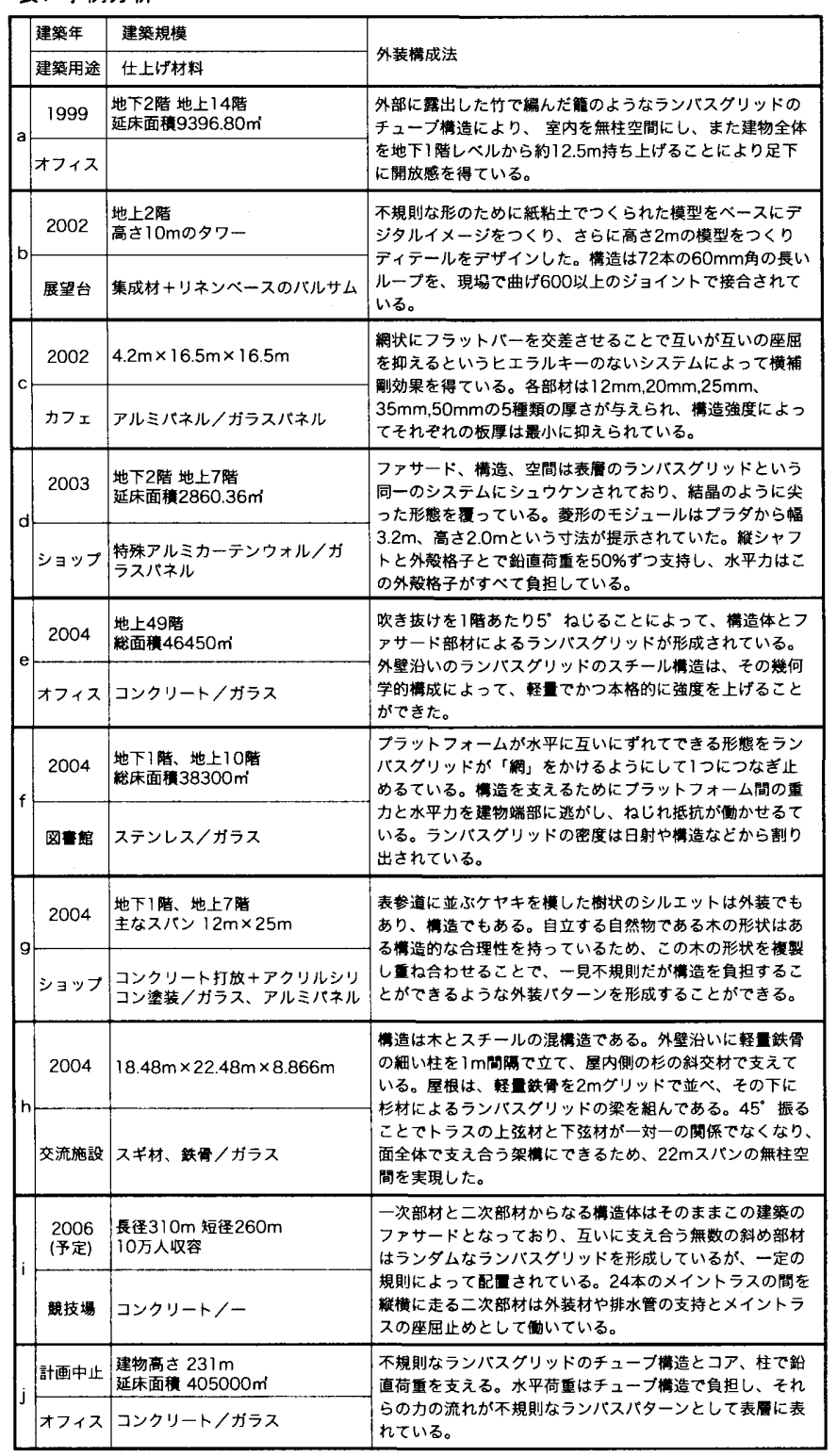

\section{表2 事例の要素寸法}

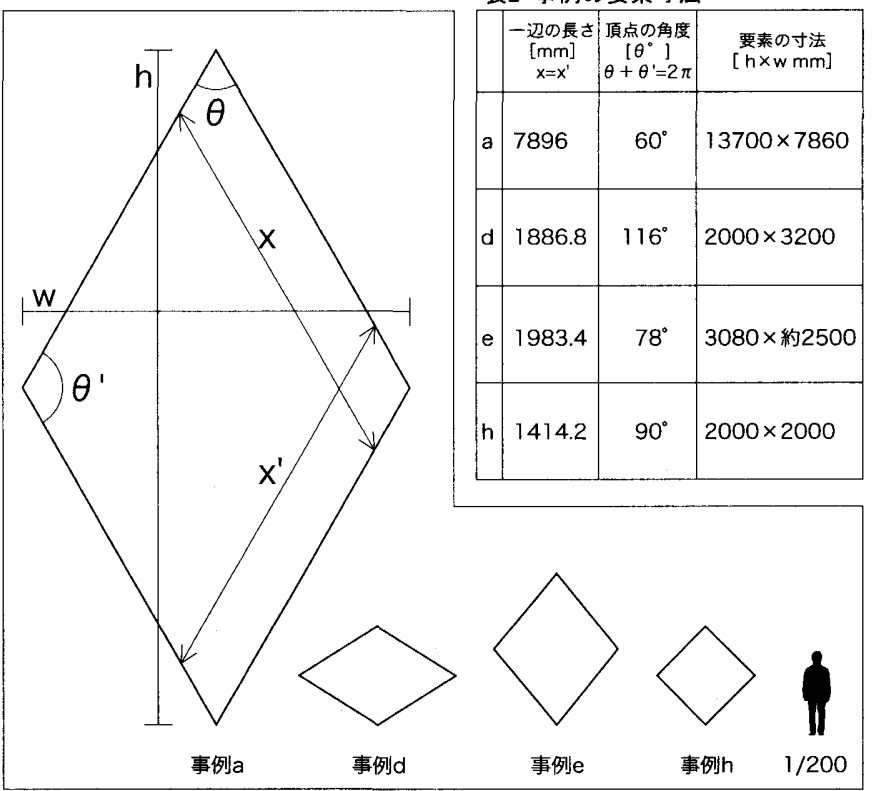

図3 事例の要素寸法概要 
配慮から構成に変化を生み出している。

事例 $(\mathrm{f})$ では、ランバスグリッドの全面に、ガラスパネルがはめら れており、室内の熱収支に関わるエネルギー効率を配慮し、最適な 日射量が透過するように、要素の形状を調整している。

事例 (b)では、発注者側に建築外観の表現に明確なイメージがある ため、要素の大きさ、形状が細かく設定されている。

事例 (c, g, i) では、パターンをランダムなものに構成し、従来の建 築の外観や印象を与える表層のデザイン性が重視され、規則性のあ るパターンや、自然における有機的なパターンの組み合わせによっ て全体が構成されている。

事例 (a) は、高層建築の特徴を活かし、大きなスケールでランバス 状外装を構成し、かつ大空間フレームによりボリュームを浮かす構 造を担い、足下に開放感を与えている。

事例 (e)は、逆に外壁沿いの巨大なランバス状の構造体を外装の内 側に配置しておう、外装は構造体が作るランバスパターンをさらに 小割りにしたガラスパネルで覆ってスケール感を抑えている。

全体的に、ランバス状外装の事例には、ランバスグリッドをなす 外装の斜交材が、鉛直シャフトやスラブなどの垂直水平材と接続す ることで相互扶助効果を確保するという共通性が見られ、構造的に も有効となる外装パターンといえる。

以上より、ランバス状外装の構成要素である等辺四角形の形状の 決定要因は、構造、日射の透過度、発注者の要求など様々な要因で

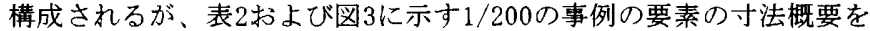
見ると、大きさは、事例 $\mathrm{a}$ を除く 3 事例は一辺の長さは1000 - $2000 \mathrm{~mm}$ の要素によるパターンであり、構造的要因などによって特別な寸法 が設定されない限り、一定範囲内の大きさが選択されていることが わかる。また、要素の形状については繸長な形の方が構造的安定性 が得られることで、外装パターンに採用されやすい傾向があるが、 $\theta=90^{\circ}$ 以下の極端に綐につぶれた要素のパターンになると採用さ れにくくなる傾向がある。

\section{3. 実験方法}

\section{1 概要}

ランバス状パターンの外装のテクスチヤ知覚の印象評価に影響す る要因を把握するために、等辺四角形の大きさと形状の異なる試料 を用いて、印象評価で重要と思われる評価項目について官能検查を 行った。

試料は表 3 に示す、一辺の長さaを 4 種類、頂点角度 $\theta$ を 11 種類に設 定し、これらを組み合わせによる44種類の試料を作成した。なお試 料は、ランバス状外装の形状的特性と外装パターンの事例分析にお ける構成手法による典型的な幾何学特性を考慮して作成したもので ある。なお、目地面積と試料全体の面積の比率を一定とするため、 効果的な外装パターンを採用していると評価された事例dの外装を線 図パターンへ変換し、目地面積比率を算定して、目地面樌を試料全 体の面積に対して $25 \%$ になるように設定し、建築外装として認識す るために等辺四角形は二重線とした。さらに、この検査では実際の 建築外装を想定しているため、身長 $170 \mathrm{~cm} の 人$ 人物の点景を大きさの基 淮として試料の画像に添えた。この点景はあらかじめ、人の点景の 書き込みにより、実際の大きさを想定できるかという試料のスケー ル感に関する事前調査を、数名の被験者に実施したところ、人の点 景により、建築外装のスケールをイメージすることができるとの回
答を得た結果、本手法を採用した。以上のように作成した寸法 $108 \times$ 152. $74 \mathrm{~mm}(1 / 50)$ の画像を高画質カラーレーザープリンターで光沢印 画紙に出力し、官能検查の試料として使用した。図5にランバス状外 装の試料サンプルを $1 / 400 て ゙$ 示す。官能検查は建築学を専攻する大学 生、大学院生 27 人(男 16 人、女 11 人) を対象とした。なお、被験者の 年齢や専門知識の有無が評価に影響を及ぼすと考えられるが、本研 究では限られた一年龄層、一知識層を対象とし、一定範囲の印象評 価の傾向を導きだすことを目的とした検討を行った。また検查時、 提示寸る試料は建築外装を想定し、これを線図パターンへ単純化し たものであるという説明を文章で示し、外装材のパターンとして評 価してもらうようにした。評価項目は、近年の建築デザイン専門誌 における建築外装の評価に見られる代表的な形容詞から抽出した表 4 に示寸5項目とし、評価項目の説明について表4に示した。それらを 5 段階の判断範瞦で評価してもらい、その結果を尺度構成理論により 定量化した。

\section{4. 結果および考察}

検查の結果を、要素の大きさ・形状別に解析し、要素の物理的変 数と評価項目、および評価項目間の相関を検討した。

\section{1 物理的变数と各評価項目の関係}

物理的変数として、要素の大きさを決定する等辺四角形の一辺の 長さと、要素の形状を決定する頂点角度を設定する。心理的変数と しては、表4に示す5つの評価項目を設定し、以下では、これらの相 関について検討した。

\subsection{1 要素の形状}

図6 (a) - (e) に頂点角度と各評価項目との関係を示す。頂点角度上

表3 ランバス状外装に関する物理的諸係数

\begin{tabular}{|c|c|c|}
\hline \multirow{2}{*}{ 変数 } & $\begin{array}{l}\text { 栗来の大きさ } \\
(4 \text { 程類 })\end{array}$ & $\begin{array}{l}\text { 等辺四角形の辺の悬さ }=\mathrm{a}=b \\
\mathrm{a}=250 \mathrm{~mm} / 500 \mathrm{~mm} / 1000 \mathrm{~mm} / 2000 \mathrm{~mm} \\
(\mathrm{size} 1 / \mathrm{size} 2 / \mathrm{size} 3 / \mathrm{size})\end{array}$ \\
\hline & 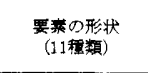 & $\begin{array}{l}\text { 頂点 } の \text { 角度 }=\theta \\
\theta=15^{\circ} / 30^{\circ} / 45^{\circ} / 60^{\circ} / 75^{\circ} / 90^{\circ} \\
\quad / 105^{\circ} / 120^{\circ} / 135^{\circ} / 150^{\circ} / 165^{\circ}\end{array}$ \\
\hline \multirow{3}{*}{ 定数 } & 要菜間の距離 & 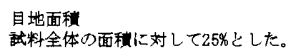 \\
\hline & 誡料全体の大光さ & $108 \times 152.74 \mathrm{~mm}(5400 \times 7636.75 \mathrm{~mm})$ \\
\hline & 維尺 & $1 / 50$ \\
\hline
\end{tabular}
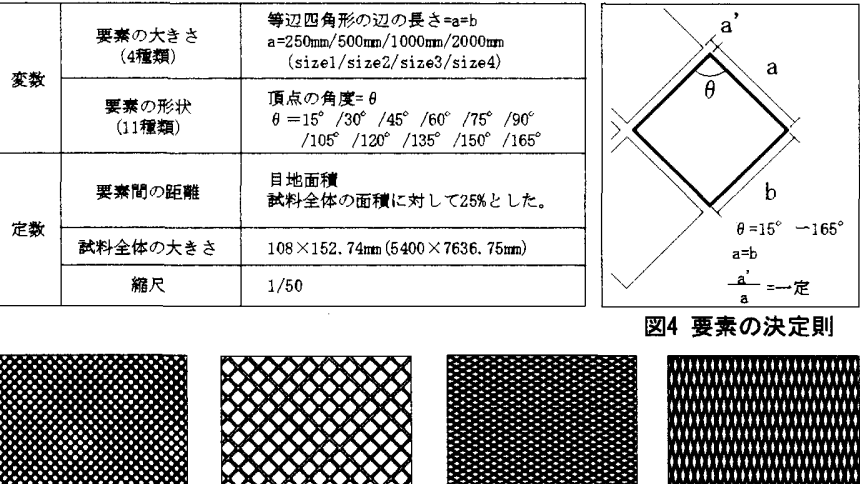

结料90-1
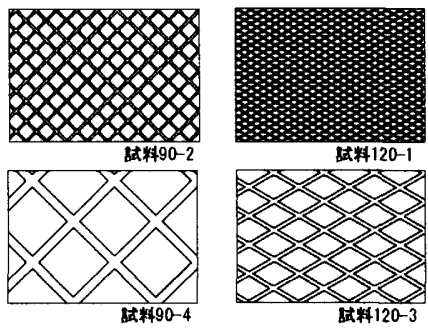

図4 要素の決定則

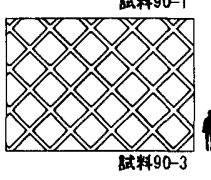

図5 ランバス状外装の試料サンプル $1 / 400$

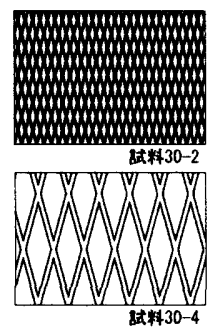

表4 官能検查の評価項目

\begin{tabular}{|c|c|c|c|c|c|}
\hline 評価項目 & 「梅雑性」 & 「集合度」 & 「好感度」 & 「新規性」 & 「方向性」 \\
\hline 判断籍垉 & 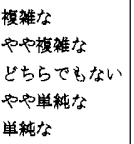 & $\begin{array}{l}\text { 図形に見える } \\
\text { やや图形に見える } \\
\text { とちちでもない } \\
\text { あまり图形に見えない } \\
\text { 四形には見えない }\end{array}$ & $\begin{array}{l}\text { 好ましい } \\
\text { やや好ましい } \\
\text { どちらでもない } \\
\text { やや好ましくない } \\
\text { 好ましくない }\end{array}$ & $\begin{array}{l}\text { 新規性がある } \\
\text { やや新規性がある } \\
\text { どちらでもない } \\
\text { あまり新规性がない } \\
\text { 新规性がない }\end{array}$ & 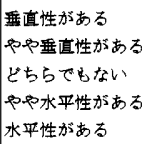 \\
\hline 内容 & $\begin{array}{l}\text { パターンに对す } \\
\text { るー教的な样伍。 }\end{array}$ & 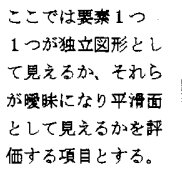 & $\begin{array}{l}\text { 建策外装として好 } \\
\text { ましいパターンか } \\
\text { の秤価。 }\end{array}$ & $\begin{array}{l}\text { ここでは建筑外装 } \\
\text { として新規性があ } \\
\text { るか、ないかを評 } \\
\text { 価する項目とする。 }\end{array}$ & $\begin{array}{l}\text { 頂点の角度に対す } \\
\text { る印象の变化。 }\end{array}$ \\
\hline
\end{tabular}




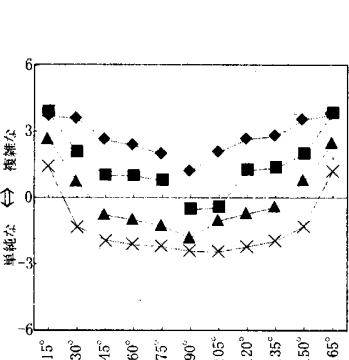

解

(a) 角度一得雑性

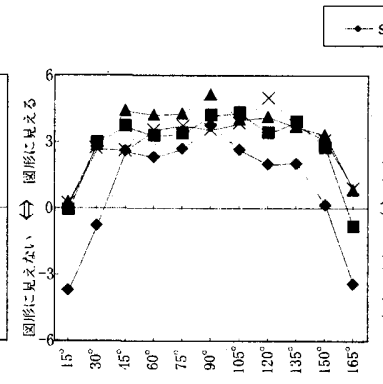

(b) 角度一集合度

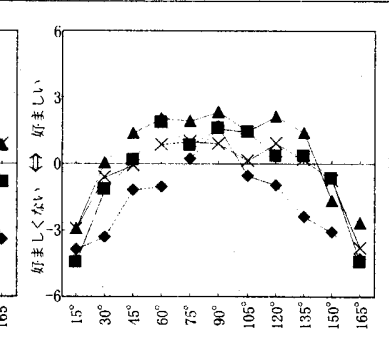

(c) 角度一好感度

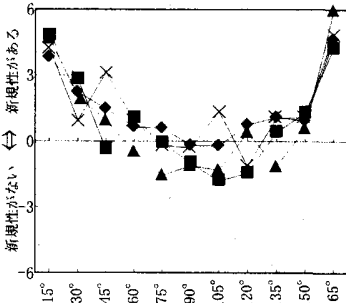

(d) 角度一新規性

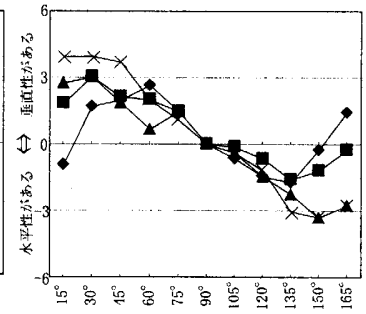

(e) 角度一方方性

図6 要素の形状と各評価項目との関係

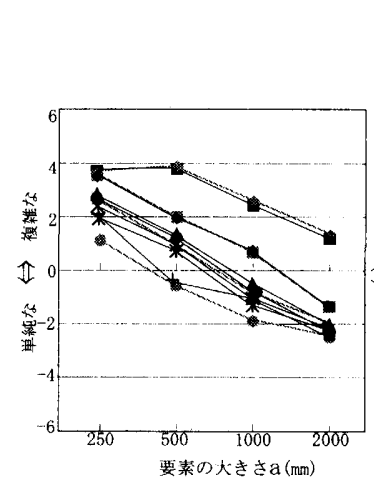

(a)要素の大きさ一複雑性

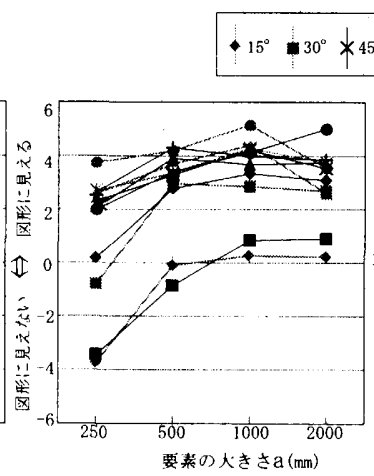

(b) 要带の大きさ一集合度

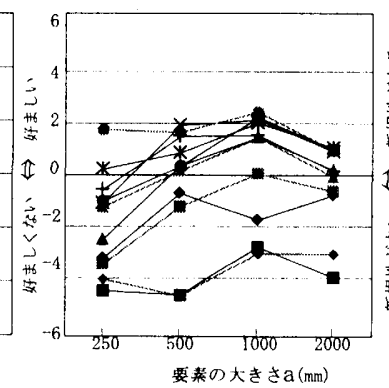

(c) 要来の大きさ一好感度

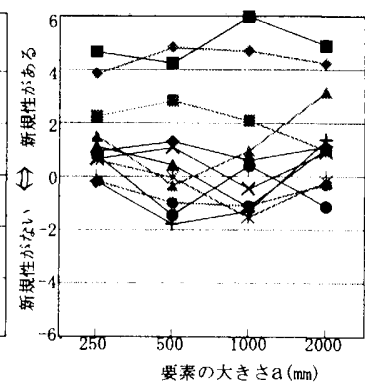

(d) 要秦の大きさー新规性

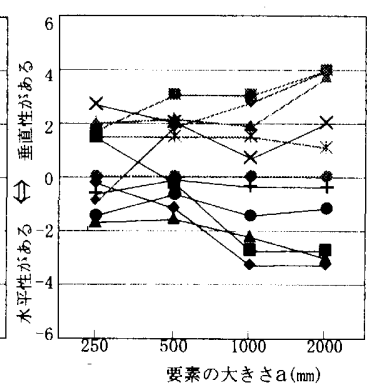

(e) 要秦の大きさ一方向性

图7 要素の大きさと各評価項目との関係

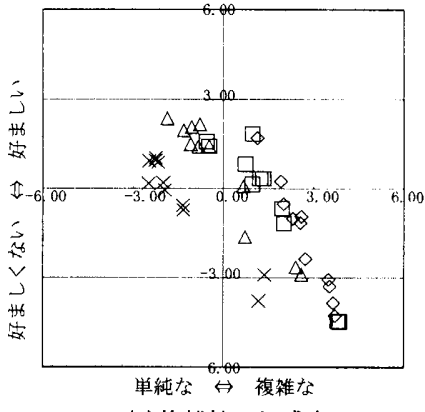

（a）複雑性一好感度

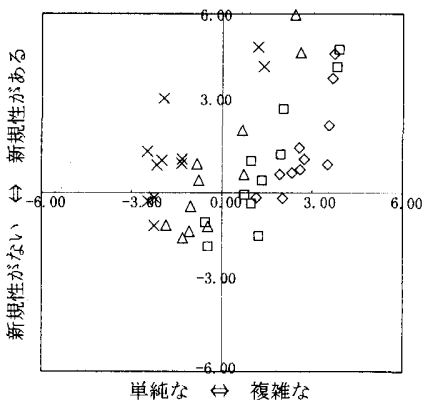

(e) 複雑性一新規性

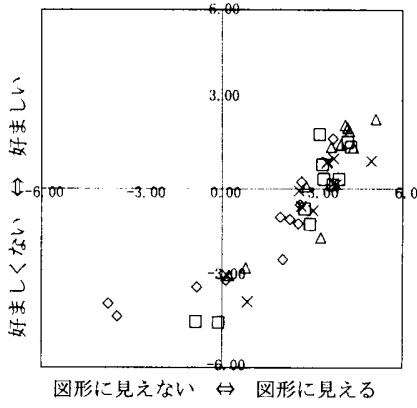

(b) 集合度一好感度

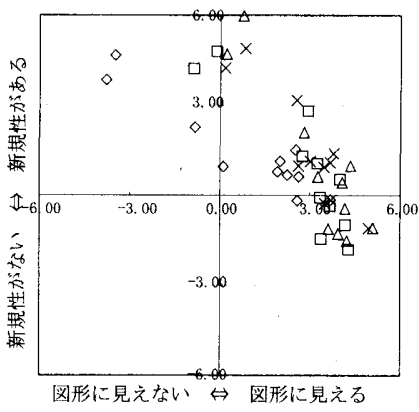

(f) 集合度一新規性

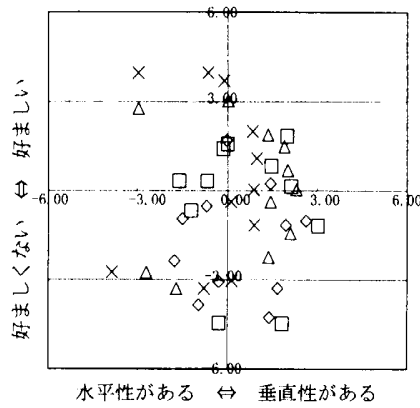

(c) 方向性一好感度

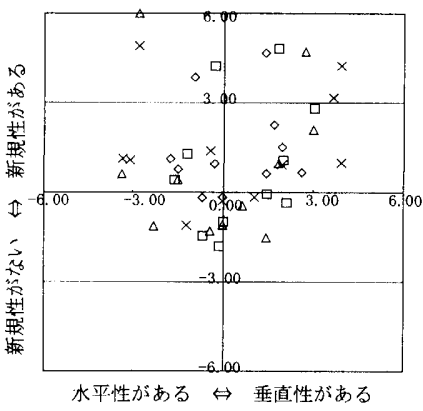

(g) 方向性一新規性

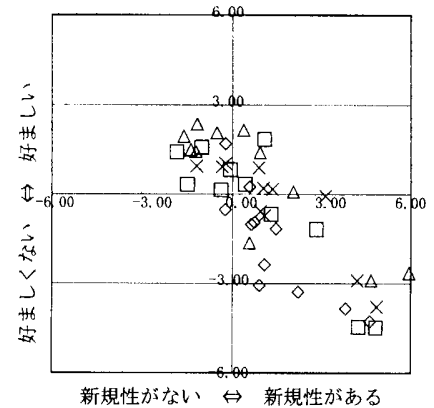

（d）新規性一好感度

\section{$\begin{array}{ll}\diamond \text { size } 1 & \triangle_{\text {size }} \\ \square \text { size } 2 & X_{\text {size } 4}\end{array}$}

は等辺四角形の特定位置の頂点の角度で要素の形状だけでなく、全 体の配列を規定する項目である。正方形を $45^{\circ}$ 傾けた等辺四角形の パターンが最も単純に感じられており、逆に縦横に細長い要素のパ ターンは複雑で新規性があると評価されていることがわかった。ま た集合度と好感度については頂点角度が $90^{\circ}$ 前後では要素が独立し た図形として知覚され、かつ好ましいと評価されている。角度と方 向性では、等辺四角形の頂点角度が減少し、要素の形状が縦長にな ると、試料の面全体の視覚的印象であるパターンとしての方向性の
評価值は減少に転じている。これは、図5の試料30-2のように頂点角 度が鋭角になると、隣接する要素同士の視覚的な相互干渉が起き、 要素よりも大きなクラスター（要素の集合）が知覚の単位として見

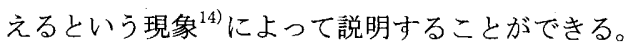

\subsection{2 要素の大きさ}

図7 (a)-(e)では要素の大きさと各評価項目との関係を示す。

複雑性は要素の大きさが小さくなるほど一様に増加している。集 合度では要素が小さなものは独立した図形として知覚されにくく、 
size2、size3、size4の辺りで最大值を示し、size1では全体的に集 合度の評価值が減少し、一つ一つの要素に対する視覚的認識が曖昧 になる。これはsize1のように、人のスケールに比べて小さな外装パ ターンでは、1つの要素よりもそれを含むより大きなクラスターとし て知覚されるようになることを示している。好感度はsize3で最大值 を示すが、size3は一辺の長さが $1000 \mathrm{~mm}$ 等辺四角形のパターンであ り、人のスケールに近いため独立図形としても知覚されやすく、好 ましさに重要な影響を及ぼしていると考えられる。新規性では全体 的に評価が高い。これは、ランバス状パターン自体が建築の外装材 として実際に目新しく、また従来の建築のもつ印象とは全く違った ものになるために高い評価が得られたと考えられる。方向性では、 頂点角度が $\theta=15^{\circ} 、 165^{\circ}$ あたりでの大きさによる評価值の変動が 大きく、小さな要素のパターンになると、要素が集合することで見 えてくるパターンとしての方向性が知覚されるようになる。

\section{2 各評価項目間の関係}

$5 つ$ 評価項目は複雑性、集合度、方向性などのパターンの幾何学 特性を問う項目と、好感度、新規性など建築外装に対する個人的な 嗜好量や既成概念を問 うち個人的な感覚を示す好感度と新規性について他の評価項目との 相関を検討する。

\section{2.1 好感度}

図8 (a)-(d)に好感度と各評価項目との関係を示す。集合度と好感 度の関保は相関が強く、図形が独立して知覚されると好ましいと評 価されるという傾向が見られる。外装材としてパターンの要素はあ る程度の大きさを持ち、独立した図形として知覚される方が好まれ ることが確認できた。複雑性は新規性と同じような傾向があり、複 雑性と新規性の相関が強いことがわかる。より単純と感じられるパ ターンが好感度において高い評価を得ている。つまり、角度が $90^{\circ}$ 付近でsize3, 4である要素のパターンは単純に感じられ、好まれる傾 向があることを示している。また方向性と好感度のグラフを見ると 原点を中心として円を描くように評価值が与えられており、角度に よって方向性と好感度の評価值の関係が変化するような周期性があ ると思われる。

\section{2.2 新規性}

新規性と各評価項目との関係を図8 (e)- $(\mathrm{g})$ に示寸。新規性と好感 度では新規性がないと感じられるパターンが好まれる傾向があり、 建築の用途や目的にもよるが外装として目新しいものが必ずしも好 まれるわけではないことが確認された。複雑性は新規性との相関が 強く、より複雑なパターンは目新しいという評価をうけることがわ かった。また集合度と新規性との関係では、要素が独立した図形と して知覚されるものは、やや目新しいという傾向が見られる。また 要素が扁平な形状の場合、小さな寸法の場合など、独立図形として は知覚されないものは、新規性は全くないという傾向が見られた。 方向性は新規性との相関は弱いが、全体的に垂直性が感じられる外 装パターンの方が水平性があると感じられるものより新規性の評価が やや高い。

\section{3 事例分析と実験結果との関係}

以上の実験結果について、2章で述べた事例分析結果と照らし合わ せてみると、外装構成要素である等辺四角形は、実際には、構造や 日射の透過度、顧客の要求など様々な決定要因で形状と大きさが決 定されるが、その大きさは実験で評洒の高かったsize3に近い寸法で あり、その形状は構造的に安定しているという理由から、縦長の形 状の要素が採用されやすいと考えられる。このように、外装構成要 素の形状や大きさは様々な要因で決められており、印象評価の観点 のみから幾何学形状が規定されることはないが、結果的に、比較的 印象評価の高い外装パターンが実際の外装の事例にも採用されてい ることが確認された。

\section{5. まとめ}

本研究から以下に示すことが明らかとなった。

(1) 要素の等辺四角形の一辺が $1000 \mathrm{~mm}$ で単純な $\theta=90^{\circ}$ の外装パター ンで好感度の評価值は最大を示しており、本官能検査の範囲内で、 ある一定の最適な大きさ、形が示された。

(2)ランバス状パターンの外装構成要素が独立図形として知覚される 場合は、好ましいと評価される傾向がある。

(3) ランバス状パターンの外装構成要素が縌長形状の場合は水平性、 横長形状の場合は垂直性が、試料面全体のパターンの視覚的印象 として評価される傾向がある。

（4）ランバス状パターンの外装が目新しいと感じられる場合は、外装 材として好ましいという評価にはつながらない。

（5）ランバス状外装の事例分析では、様々な要因で外装構成要素の形 状や大きさは決められているが、結果的に比較的印象評価の高い 外装パターンが採用されている。

\section{参考文献}

1) 柣橋修: 構築されるマテリアリティ, 建築文化 No. 662, pp. 94-95, 2002. 12 2) 中埜良昭, 藤井賢志, 楠浩一, 久松嘉那子, 岡田恒男 : 鉄筋コンクリート造学校 建築の耐震補強に関する事例分析（その1 全体の概要），日本建築学会大 会学術講演梗概集, C-2分冊, p. 30-31, 1999年

3) 岡島達雄, 河辺伸二, 溝口雄一, 久野雅士 : コンクリート素地仕上げの視覚 心理学的評価, コンクリート工学論文集, 第5巻第 2 号, 1994.7

4) 土屋潤,槅高義典, 田村雅紀：建築石材仕上げの視覚的評価の及ぼす表面性 状の影響に関する研究 その2 砂岩の表面性状が視覚的評価に及ぼす影響, 日本建築学会構造系論文集, 第584号, pp. 37 41, 2004. 10

5) 松山祐子, 橘高義典, 田村雅紀 : 景観材料のエイジング評価に及ぼす色彩特性 の影響に関する研究 その2 レンガ風仕上げモザイクパターンがエイジン グ評価に及ぼす影響, 日本建築学会構造系論文集, 第586号, pp. 23-27, 2004. 12 6) 北村薫子, 磯田憲生 : 内装材のテクスチャーが視環境評価に及ぼす影響 第 5 報 質感評価に基づいた建築仕上げ材の分類, 日本建築学会大会学術講演梗 概集, pp. 435-436, 1999.9

7)稲本淳平, 吉沢望, 平手小太郎 : テクスチャーの違いが室内の印象評価に与え る影響 テクスチャーのパターンと色彩の分離, 日本建築学会大会学術講演 梗概集, pp437-438, 1999.9

8) 大野隆造, 小室清隆, 茶谷正洋: テクスチャの視覚に関する研究 第5報 テ クスチャの知覚領域, 日本建築学会計画系論文報告集, 第395号, pp. 31-37, 1989. 1

9) a+u, 2002年2月臨時増刊 H\&deM ヘルツォーグ・アンド・ド・ムロン 19782002, 2002. 2

10) 南泰裕: ランバス・グリッド, 建築文化 No. 669 , p. 116, 2004. 2

11) 新建築 2002 年 3 月号別冊 大江匡 リキッド・スペース, pp. 140-145, 2002 12）日経アーキデクチャー,pp. 48-58, 2004.10.4 13) 新建築, 2004年11月号 pp. 108-115,2004.11 14) Kurt Koffka(著), 鈴木正弥(訳)：ゲシュタルト心理学の原理, 1998.10 15)大山 正他 : 新編 感覚・知覚 心理学 ハンドブック,pp. 946-965, 1994.2 